\title{
An Assessment of Treated Greywater Reuse in Irrigation on Growth and Protein Content of Prosopis and Albizia
}

\author{
Naji K. Al-Mefleh ${ }^{1}$, Yahia A. Othman ${ }^{2, * \mathbb{D}}$, Maher J. Tadros ${ }^{1} \mathbb{D}$, Amani Al-Assaf ${ }^{3}$ (D) and Samer Talozi ${ }^{4} \mathbb{D}$ \\ 1 Department of Natural Resources and Environment, Jordan University of Science and Technology, \\ Irbid 22110, Jordan; nmefleh@just.edu.jo (N.K.A.-M.); mtadros@just.edu.jo (M.J.T.) \\ 2 Department of Horticulture and Crop Science, The University of Jordan, Amman 11942, Jordan \\ 3 Department of Agricultural Economics and Agribusiness, The University of Jordan, Amman 11942, Jordan; \\ amani.alassaf@ju.edu.jo \\ 4 Department of Civil Engineering, Jordan University of Science and Technology, Irbid 22110, Jordan; \\ samerbse@just.edu.jo \\ * Correspondence: ya.othman@ju.edu.jo; Tel.: +962-779695781
}

Citation: Al-Mefleh, N.K.; Othman, Y.A.; Tadros, M.J.; Al-Assaf, A.; Talozi, S. An Assessment of Treated Greywater Reuse in Irrigation on Growth and Protein Content of Prosopis and Albizia. Horticulturae 2021, 7, 38. https://doi.org/10.3390/ horticulturae7030038

Academic Editor: Genhua Niu

Received: 3 February 2021

Accepted: 20 February 2021

Published: 25 February 2021

Publisher's Note: MDPI stays neutral with regard to jurisdictional claims in published maps and institutional affiliations.

Copyright: (c) 2021 by the authors. Licensee MDPI, Basel, Switzerland. This article is an open access article distributed under the terms and conditions of the Creative Commons Attribution (CC BY) license (https:/ / creativecommons.org/licenses/by/ $4.0 /)$.

\begin{abstract}
This study investigated the influence of treated greywater on growth and protein content of multipurpose (forage and ornamental) transplants, Prosopis juliflora L., Prosopis tamarugo L., and Albizia lebbeck L. Transplants of tested species were irrigated with treated greywater, diluted greywater (grey + distilled water, 1:1/by volume), and distilled water (control) for seven months. Water quality analysis showed that the concentrations of nutrients and heavy metals found in the greywater were within the acceptable range compared with Jordan Institution for Standard and Metrology (JISM) and the World Health Organization (WHO) thresholds for safe use of greywater. Escherichia coli found in the greywater were lower compared to JISM and WHO guidelines for the safe use of greywater. Irrigation with treated greywater increased shoot fresh weight by $24-39 \%$ and dry weight by $34-40 \%$ compared to diluted greywater and control. No significant difference in crude protein was noticed between water treatments. Prosopis species (P. juliflora Albizia lebbeck L. and P. tamarugo Albizia lebbeck L.) had higher shoot fresh (35\%) and dry weight the same species had lower crude protein (44\%) when compared to Albizia lebbeck Albizia lebbeck L. The reuse of treated greywater for landscaping or forage production alleviates the demand for water resources and reduces the pressure on wastewater treatment plants. However, considering the controversial findings of previous studies on greywater quality (especially, long-term reuse), the reuse of treated greywater needs to be considered with caution and periodic quality analyses and economic assessments are required.
\end{abstract}

Keywords: water management; ornamentals; heavy metals; legumes; protein; Escherichia coli

\section{Introduction}

High demand for water due to the growth in population coupled with frequent drought during the last decades has encouraged governments to adopt new innovations to ensure the sustainable management of water resources, such as water harvesting and the reuse of waste- and greywater for agriculture, such as landscaping [1,2]. The use of wastewater for irrigation might present negative effects, especially environmental contamination and toxicity [3]. Wastewater contains toxic microorganisms and heavy metals, such as chromium $(\mathrm{Cr})$, cadmium $(\mathrm{Cd})$, nickel $(\mathrm{Ni})$, lead $(\mathrm{Pb})$, and mercury $(\mathrm{Hg})$, which can induce severe risks to plant, human, and the environment [3]. However, rainwater harvesting, greywater recycling, and hybrid rainwater-greywater systems are less harmful to the environment and can mitigate urban water scarcity at both domestic residential dwelling and commercial building scales $[1,4]$. The hybrid rainwater harvesting-greywater systems had the highest mains water savings (55.3\%), lowest environmental impact, and was the second-fastest system to become financially effective at USD $5.20 \mathrm{~m}^{-3}$ (rainwater harvesting, USD $2.00 \mathrm{~m}^{-3}$ ) when compared to centralized mains water system [4]. 
Greywater is defined as wastewater from kitchen, bathroom, or laundry without any input from toilets [5]. While wastewater originating from toilets comprises a significant amount of residential waste, greywater fraction accounts for about $70 \%$ of the total residential wastewater [6]. Therefore, the investment in greywater reuse can potentially reduce wastes by converting a significant fraction of wastewater to a suitable water source $[6,7]$. Greywater reuse is a common practice in both developed and developing countries as a coping strategy to sustain water resources [8]. Greywater has substantial benefits for non-potable reuse applications such as irrigation and toilet flushing [9]. In fact, treated greywater is a viable approach and a potential source of water that alleviates the demand and pressure on freshwater for food production [8]. This is because most water conservation methods are ineffective, expensive, and might require expertise in addressing water challenges, specifically in developing countries.

Greywater reuse is essential for sustainable water management in arid lands, promoting the preservation of the limited freshwater resources, and reducing environmental pollution and overall input costs [10]. In the last two decades, several research studies assessed the environmental, economic, and energetic benefits of the reuse of greywater as a potential secondary source of water and represent a viable opportunity for the sustainable management of water resources [7]. Generally, all types of greywater have good biodegradability [11]. After six months of greywater (electrical conductivity $\left(\mathrm{EC}_{\mathrm{W}}\right)=1.83 \mathrm{dS} \mathrm{m}^{-1}$, sodium adsorption ratio $(\mathrm{SAR})=3.3$ ) application, soil EC was $1.8 \mathrm{dS} \mathrm{m}^{-1}$ and SAR was 3.04. In addition, leaf nutrient (nitrogen $(\mathrm{N})$, phosphorus $(\mathrm{P})$, potassium $\left(\mathrm{K}^{+}\right)$, sodium $\left(\mathrm{Na}^{+}\right)$, chloride $\left(\mathrm{Cl}^{-}\right), \mathrm{Cd}$ and $\mathrm{Pb}$ )) from irrigated olive trees and vegetable crops (okra, bean, corn, and sunflower) were not affected [10]. A long-term study (four years) on vegetables showed that $\mathrm{pH}$ and $\mathrm{Na}^{+}$values from grey- and freshwater treatments were similar across soil profiles, $0-90 \mathrm{~cm}$ soil depth [11].

Prosopis and Albizia species are large trees or shrubs belonging to the Fabaceae family; characterized by their fast growth, $\mathrm{N}$-fixation, and adaptation to poor environments, including drought, high temperatures, and nutrient-contamination, especially heavy metals [12-14]. Prosopis and Albizia are multipurpose trees used as wood, fuel, feed for livestock, landscaping (shade, fencing), and forestation [12,15]. Albizia species, including (A. lebbeck L. and A. julibrissin L.), has been used recently in plantscaping, including in Jordan [16]. Although Prosopis spp. can be a potential threat (invasive) to arid regions, especially under unsuitable management practices, promoting the use of these species by locals is a useful strategy toward the control of their spread and gain extra income; wood, Xeriscaping, and grazing [12,17]. In fact, the estimated wood production from Prosopis trees in Sweimeh, Jordan was about 675 ton ha ${ }^{-1}$ in the extremely invaded regions [17]. The proper use of those multi-purpose species (e.g., Prosopis) can contribute to socio-economic development in rural communities [12]. However, to guarantee an aesthetic appearance in the landscape or high production (wood, fuel, grazing), frequent irrigation is a prerequisite.

Several studies had investigated the use of greywater in forestry plantations and its productivity $[18,19]$. Forestry plantations are considered as revenue to respond to the rapid increase in biomass and energy consumption worldwide $[18,20]$. In fact, short rotation forestry is considered a renewable energy source, especially for rural communities and poor people in developing countries, in addition to the substantial opportunities it offers for investments at farm and community levels $[18,19]$. Therefore, water and nutrients supply for forestry plantations through greywater reuse is of great interest in arid lands region, including Jordan.

Jordan is among the most water-scarce countries in the world with a renewable water supply that only covers approximately half of the population's water demand [21]. Accordingly, the adoption of the greywater approach for the sustainable conservation of water in countries of the eastern Mediterranean region (including Jordan) is inevitable [2]. The objective of this study was to assess the influence of treated greywater reuse on the growth and protein content of $P$. juliflora L., P. tamarugo L., and Albizia lebbeck L. 


\section{Materials and Methods}

\subsection{Experiment Setup and Plant Material}

The study was conducted in a greenhouse at the Jordan University of Science and

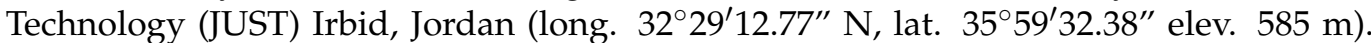
Prosopis juliflora L., Prosopis tamarugo L., and Albizia lebbeck L. were collected from JUST Arboretum and were sown in $5 \mathrm{~L}$ pots filled with a growing substrate composed of sandyloam soil + peat moss (2:1/by volume). Media $\mathrm{pH}$ was 6.8 and $\mathrm{EC}_{\mathrm{w}}$ was about $1 \mathrm{dS} \mathrm{m}^{-1}$. Pots were placed on a bench table in the greenhouse. Mean temperatures, relative humidity, and light intensity during the study period were $25^{\circ} \mathrm{C}, 50 \%$, and $1100 \mu \mathrm{mol} \mathrm{s}{ }^{-1} \mathrm{~m}^{-2}$.

\subsection{Greywater Sources and Quality Analyses}

Treated greywater used in this study was from the confined trench unit developed by the JUST to reuse greywater from student dorms (Figure 1). The filtration unit consists of an impervious plastic trench filled with different sizes of gravel and a sand layer (at the base). Gravel filter media at the top layer of the unit ranged from $20 \mathrm{~mm}$ to $30 \mathrm{~mm}$ in diameter, while the lower layer was between $2 \mathrm{~mm}$ and $5 \mathrm{~mm}$. Sand particles' size ranged from $0.05 \mathrm{~mm}$ to $1.0 \mathrm{~mm}$. Greywater used in the study was collected from the posttreatment holding tank (treated greywater). Water quality analysis for treated greywater was conducted prior to irrigation following the procedures of Al-Hamaiedeh and Bino [10]. Quality analyses included $\mathrm{pH}, \mathrm{EC}_{\mathrm{w}}$, biological oxygen demand (BOD), chemical oxygen demand (COD), total dissolved solids (TDS), SAR, exchangeable sodium percentage (ESP), nitrate $\left(\mathrm{NO}_{3}\right), \mathrm{N}$, calcium $\left(\mathrm{Ca}^{+2}\right)$, magnesium $\left(\mathrm{Mg}^{+2}\right), \mathrm{K}^{+}, \mathrm{Na}^{+}, \mathrm{Cl}^{-}$, zinc $(\mathrm{Zn})$, iron $(\mathrm{Fe})$, boron (B), arsenic (As), $\mathrm{Cd}, \mathrm{Pb}$, and Escherichia coli.

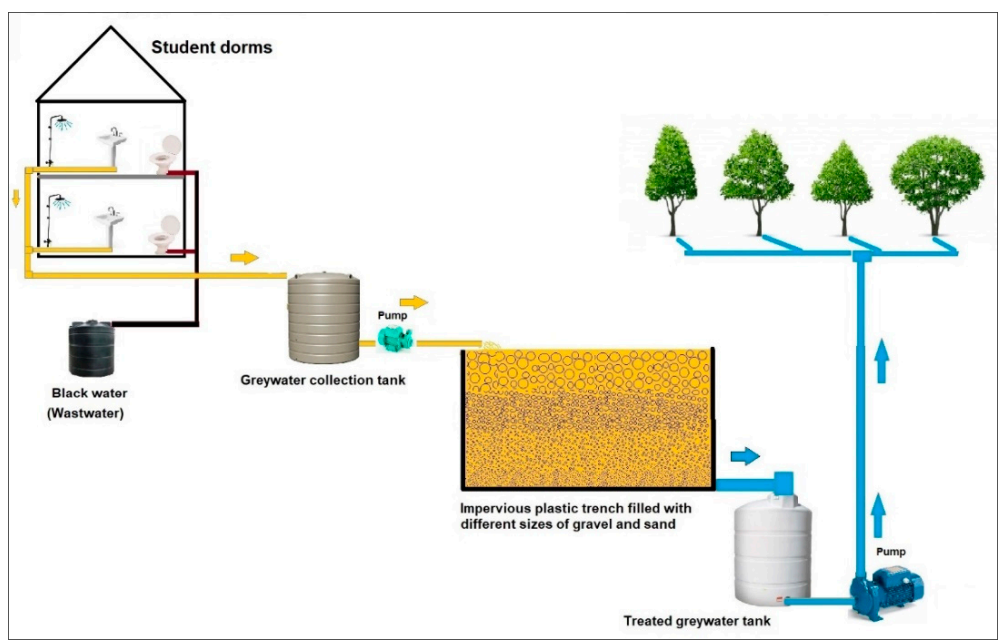

Figure 1. Schematic diagram for the greywater treatment unit.

\subsection{Treatment}

During the study period, the following treatments were evaluated: control (distilled water), treated greywater and a mixture of greywater, and distilled water (1:1/by volume). The experiment was designed as a complete randomized block design with three replicates. The tested species were irrigated twice a week. Tested species shoots were recut three times during the growing season (seven months). Shoot fresh and dry weight and total $\mathrm{N}$ were determined for each treatment and across the three cuttings. Total nitrogen was determined by the Kjeldahl Method. Shoot protein content was then derived by multiplying the N\% by 6.25 .

\subsection{Statistical Analysis}

A randomized complete block design with three replications and two factors (three water sources, three plant species) was used. The analysis of variance (ANOVA) and the 
least significant difference test $(p=0.05)$ in Statistical Analysis System (SAS; Version 9.3 for Windows; SAS Institute, Cary, NC, USA) were used to identify differences between water sources.

\section{Results and Discussion}

\subsection{Greywater Quality and Plant Yield}

The quality of treated greywater was assessed for reuse in irrigation according to (Jordan Institution for Standard and Metrology (JISM)) and the World Health Organization (WHO) (Table 1) [2,22]. The concentrations of nutrients and heavy metals $\left(\mathrm{N}, \mathrm{Ca}^{+2}, \mathrm{Mg}^{+2}\right.$, $\left.\mathrm{K}+, \mathrm{Na}+, \mathrm{Cl}-, \mathrm{Zn}, \mathrm{Fe}, \mathrm{B}, \mathrm{As}, \mathrm{Cd}, \mathrm{Pb}, \mathrm{NO}_{3}, \mathrm{PO}_{4}\right), \mathrm{pH}, \mathrm{EC}_{\mathrm{W}}, \mathrm{BOD}, \mathrm{COD}$, TDS, ESP, and Escherichia coli found in the greywater were within the acceptable range compared to the Jordan Institution for Standard and Metrology (JISM) and the World Health Organization (WHO) guidelines for the safe use of greywater. The evaluation of reusing greywater in home gardens in water-limited environments showed that greywater can be reused for home gardening when diluted with fresh water [23]. This is because average $\mathrm{pH}(8-9)$, SAR (1-10), Soluble Sodium Percent $(68-92 \%)$, and $\mathrm{Cl}^{-}\left(-30\right.$ meq $\left.{ }^{-1}\right)$ values from tested sites were found to be within the acceptable range [23].

Table 1. Quality of treated greywater compared with allowable Jordanian standard limit for irrigation (Jordan Institution for Standard and Metrology (JISM)) and the World Health Organization (WHO) [2,22].

\begin{tabular}{|c|c|c|c|}
\hline Parameter & Treated Greywater & JISM & WHO \\
\hline $\mathrm{pH}$ & 7.9 & $6.0-9.0$ & $6.5-8.0$ \\
\hline $\mathrm{EC}_{\mathrm{w}}\left(\mathrm{dS} \mathrm{m}^{-1}\right)$ & 0.7 & $1.0-3.0$ & $0.7-3.0$ \\
\hline $\mathrm{N}\left(\mathrm{mg} \mathrm{L}^{-1}\right)$ & 17.7 & 50 & $5-30$ \\
\hline $\mathrm{Ca}^{+2}\left(\mathrm{mg} \mathrm{L}^{-1}\right)$ & 71.9 & 400 & - \\
\hline $\mathrm{Mg}^{+2}\left(\mathrm{mg} \mathrm{L}^{-1}\right)$ & 17.3 & 60 & - \\
\hline $\mathrm{K}^{+}\left(\mathrm{mg} \mathrm{L}^{-1}\right)$ & 5.1 & 80 & - \\
\hline $\mathrm{Na}^{+}\left(\mathrm{mg} \mathrm{L}^{-1}\right)$ & 43.5 & 230 & 69-207 \\
\hline $\mathrm{Cl}^{-}\left(\mathrm{mg} \mathrm{L}^{-1}\right)$ & 85.1 & 400 & $140-350$ \\
\hline $\mathrm{Zn}\left(\mathrm{mg} \mathrm{L} \mathrm{L}^{-1}\right)$ & 0.7 & 2.0 & $<2.0$ \\
\hline $\mathrm{Fe}\left(\mathrm{mg} \mathrm{L}^{-1}\right)$ & 0.1 & 5.0 & $0.1-1.5$ \\
\hline $\mathrm{B}\left(\mathrm{mg} \mathrm{L}^{-1}\right)$ & 0.4 & 1.0 & $0.7-3.0$ \\
\hline As $\left(\mathrm{mg} \mathrm{L}^{-1}\right)$ & $<0.002$ & 0.1 & $<0.1$ \\
\hline $\mathrm{Cd}\left(\mathrm{mg} \mathrm{L}^{-1}\right)$ & $<0.002$ & 0.01 & $<0.01$ \\
\hline $\mathrm{Pb}\left(\mathrm{mg} \mathrm{L}^{-1}\right)$ & $<0.01$ & 5.0 & $<5.0$ \\
\hline $\mathrm{BOD}_{5}\left(\mathrm{mg} \mathrm{L}^{-1}\right)$ & 12.9 & 60 & - \\
\hline $\operatorname{COD}\left(\mathrm{mg} \mathrm{L}^{-1}\right)$ & 29.6 & 120 & - \\
\hline $\mathrm{PO}_{4}\left(\mathrm{mg} \mathrm{L}^{-1}\right)$ & 0.2 & 30 & - \\
\hline $\mathrm{NO}_{3}\left(\mathrm{mg} \mathrm{L}^{-1}\right)$ & 2.0 & 45 & 50 \\
\hline $\operatorname{TDS}\left(\mathrm{mg} \mathrm{L}^{-1}\right)$ & 429 & $<2000$ & $450-2000$ \\
\hline SAR (ratio) & 21.9 & 9.0 & $<13$ \\
\hline $\operatorname{ESP}(\%)$ & 0.5 & - & - \\
\hline $\operatorname{coli}\left(\right.$ no. $\left.100 \mathrm{~mL}^{-1}\right)$ & 408 & $<10^{3}$ & $10^{4}-10^{5}$ \\
\hline
\end{tabular}

$\mathrm{EC}_{\mathrm{W}}$, electrical conductivity; $\mathrm{BOD}$, biological oxygen demand; COD, chemical oxygen demand; TDS, total dissolved solids; SAR, sodium adsorption ratio; ESP, exchangeable sodium percentage; E. coli, Escherichia coli.

Escherichia coli is a coliform group of bacteria that used to model the pathogenic bacteria in reused water and their behavior is expected to reflect enteric pathogens [2]. A long-term study (8-18 years) on the impact of greywater disposal on soil showed that greywater irrigated soils had higher $\mathrm{pH}, \mathrm{P}$, and microbial activity [24]. A $\mathrm{pH}$ value of 9 and Escherichia coli up to $10^{3} \mathrm{MPN} \mathrm{g}^{-1}$ was recorded for some greywater-treated soil locations. Higher microbial activity in greywater-treated soils may be beneficial for plant growth but Escherichia coli levels may be a risk to human health [24]. In this study, Escherichia coli numbers in the treated water $(408$ per $100 \mathrm{~mL})$ were lower than the WHO standards $\left(10^{4}-10^{5}\right.$ per $\left.100 \mathrm{~mL}\right)$. Therefore, Escherichia coli counts in treated greywater resulted in 
acceptable risk. Our results were similar to Disha et al. [25], who concluded that treated greywater is bacterially safe and has a positive impact on plant growth. Given that Escherichia coli could exceed the safe limit (long-term reuse), periodic soil and water quality test is essential when greywater is the main source for irrigation.

Irrigation with treated greywater increased shoot fresh weight by $24-39 \%$ and dry weight by $34-40 \%$ compared to diluted greywater and control (Table 2). That shoot growth increased in parallel with increased greywater ratio (control-diluted-greywater) is consistent with the results for pepper (Capsicum annuum L.) [25] cabbage (Brassica oleracea L.) and onion (Allium cepa L.) [26]. A higher growth rate can be attributed to higher nutrient levels in greywater water compared to control (Table 1). Nutrient levels play a key role in plant morpho-physiology such as photosynthesis, root and shoot growth, and flower and fruit quality [27-31].

Table 2. Shoot fresh and dry weight (total yield per plant) and crude protein (\%) of Prospois juliflora L., Prospois tamarugo L., and Albizia lebbeck L. seedling grown under different water quality treatments.

\begin{tabular}{|c|c|c|c|c|}
\hline Water Source $(\mathrm{W})$ & Species (S) & $\begin{array}{l}\text { Shoot Fresh wt. } \\
\quad\left(\text { g plant }^{-1}\right)\end{array}$ & $\begin{array}{l}\text { Shoot Dry wt. } \\
\left.\text { (g plant }^{-1}\right)\end{array}$ & $\begin{array}{c}\text { Crude Protein } \\
(\%)\end{array}$ \\
\hline Distilled water & & $60.9 \mathrm{~b}$ & $32.7 \mathrm{~b}$ & 11.2 \\
\hline Distilled+greywater & & $68.3 \mathrm{~b}$ & $34.0 \mathrm{~b}$ & 11.6 \\
\hline \multirow[t]{4}{*}{ Greywater } & & $84.8 \mathrm{a}$ & $45.7 \mathrm{a}$ & 10.9 \\
\hline & Prosopis juliflora L. & $74.4 \mathrm{a}$ & $39.4 \mathrm{a}$ & $8.80 \mathrm{~b}$ \\
\hline & Prosopis tamarugo L. & $76.6 \mathrm{a}$ & $41.0 \mathrm{a}$ & $9.00 \mathrm{~b}$ \\
\hline & Albizia lebbeck L. & $63.0 \mathrm{~b}$ & $32.0 \mathrm{~b}$ & $16.0 \mathrm{a}$ \\
\hline \multirow[t]{3}{*}{$p$-value } & W & $<0.0001$ & $<0.0001$ & 0.68 \\
\hline & S & 0.006 & 0.001 & $<0.001$ \\
\hline & $\mathrm{W} \times \mathrm{S}$ & 0.08 & 0.13 & 0.89 \\
\hline
\end{tabular}

Different letters indicate differences among treatments according to Fisher's Least Significant Difference (LSD) test $(p \leq 0.05)$.

The significant increase in shoot growth is coupled normally with a reduction in nutrient and protein concentration in the tissues due to the dilution effect [32]. In this study, the dilution effect was noticed in Prosopis species compared to Albizia (Table 2). This significant increase in shoot growth of Prosopis seedling (35\%) induced the dilution phenomena and consequently reduced protein (\%) in the same tissues by $44 \%$. Interestingly, when shoot dry weight of treated greywater treatment increased by $40 \%$ (compared to control), crude protein only reduced by $3 \%$. Overall, irrigation with greywater potentially improved yield and feed quality (crude protein) across the experimental period (three cuttings) and over the tested species; Prosopis and Albizia.

\subsection{Reuse of Greywater for Irrigation of Multipurpose Trees-Prosopis and Albizia}

Prosopis and Albizia species have been widely used in arid and semi-arid regions for fuel, wood, feed for animals, and ornamental woody trees $[16,17]$. This is because these species are highly adapted to harsh environments, including drought, salinity, and soil contamination [14]. Legumes (including Prosopis and Albizia) leaves are highly digestible by grazing animals and rich in protein and carbohydrates. In addition, these species provide an attractive and aesthetical view of the landscape, especially Albizia species [16]. The reuse of greywater for irrigation in the urban landscape and forage production is becoming increasingly common recently, especially in arid lands [10].

\subsubsection{Food and Forage Production}

During the study period, Prosopis and Albizia irrigated with greywater had consistently higher shoot fresh weight (compared to control, distilled water) across the three cuts (Figure 2). Similarly, shoot dry weight from greywater was higher than control across species (Figure 3). Therefore, greywater can potentially improve crop production compared to well water. 


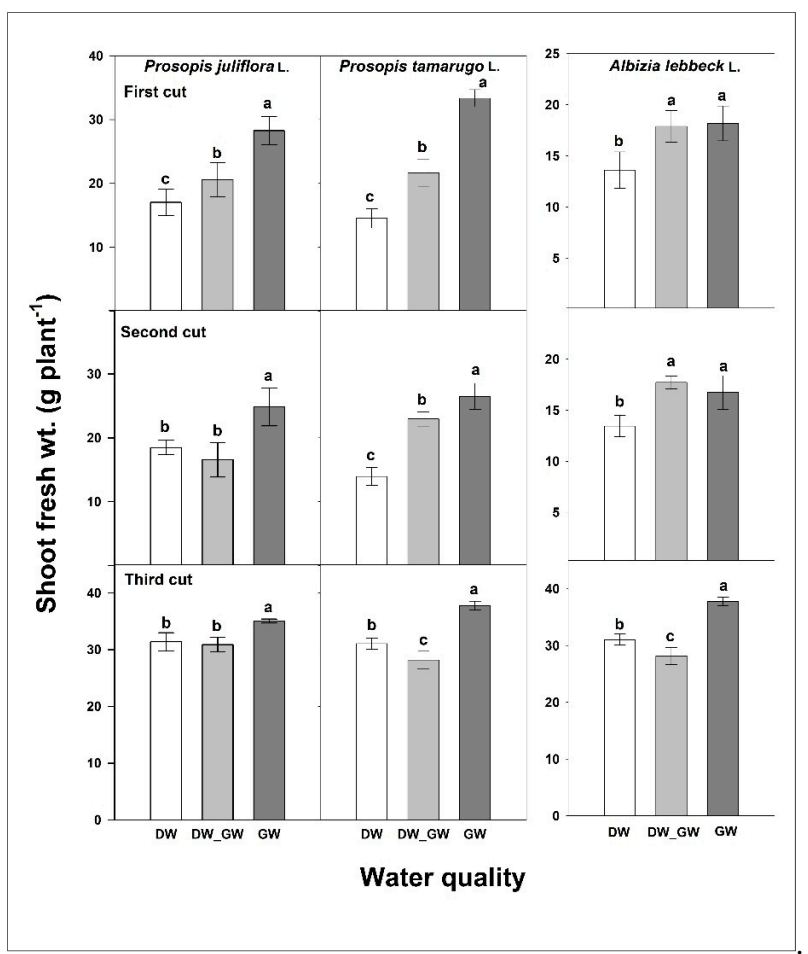

Figure 2. Fresh yield of different multipurpose tree species (Prosopis juliflora L., P. tamarugo L., and Albizia lebbeck L.) grown under different water quality treatment; distilled water (DW), distilled + greywater (DW_GW), and greywater (GW). Bars represent mean \pm standard error (SE). Different letters indicate a significant difference between treatments $(p \leq 0.05)$.

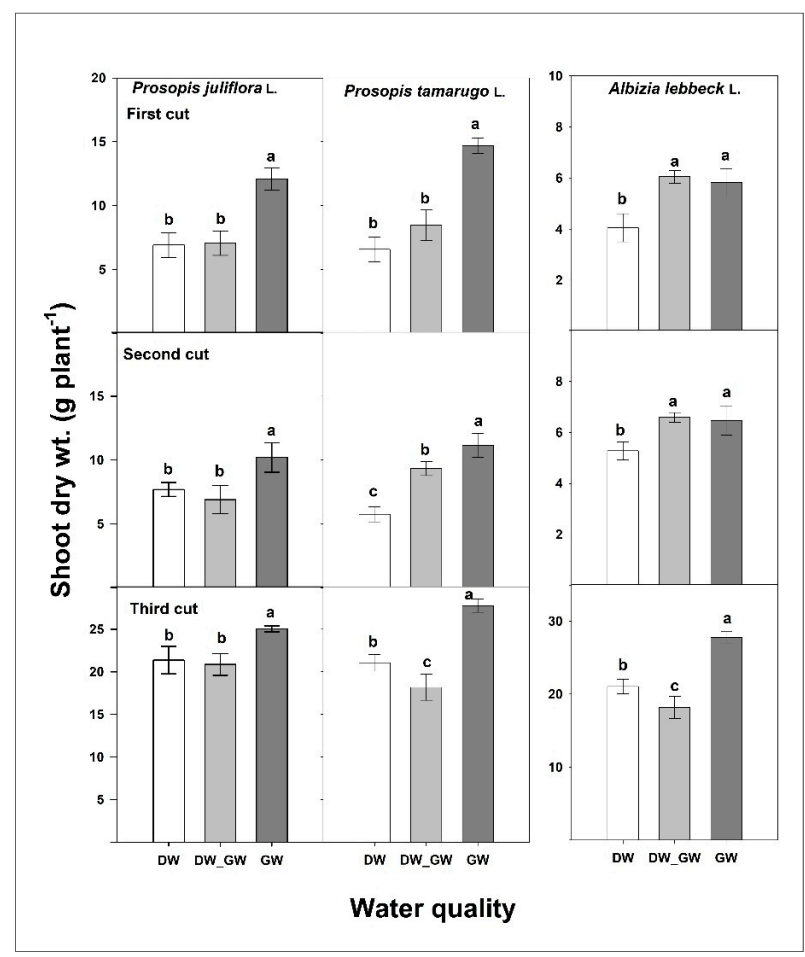

Figure 3. Fresh yield of different multipurpose tree species (Prosopis juliflora L., P. tamarugo L., and Albizia lebbeck L.) grown under different water quality treatment; distilled water (DW), distilled + greywater (DW_GW), and greywater (GW). Bars represent mean \pm SE. Different letters indicate a significant difference between treatments $(p \leq 0.05)$. 
Untreated greywater normally contains higher nutrients and bacterial populations than tap water, but the treatment process reduces the concentration of most unwanted greywater parameters and brings them into irrigation standards [25]. A recent review on quality and quantity of greywater reuse showed large variations in greywater quality and quantity associated with time and source, and the filtration treatment [33]. Interestingly, that review concluded that heavy metals and organic micro-pollutants in treated greywater rarely pose a threat to human health if recycled properly. Greywater reuse, after treatment, sustains water resources by conserving irrigation water and protects the aquatic ecosystem (freshwater ecosystem) from the adverse effect of wastewater [25]. Despite these high counts of fecal coliforms $\left(4 \times 10^{5} / 100 \mathrm{~mL}\right)$ and fecal streptococci $(2000 / 100 \mathrm{~mL})$ in greywater, no significant difference in contamination levels was found between crops (carrots and lettuce) irrigated (eight weeks) with greywater and tap water [34]. Shi et al. [35] assessed the microbial risk of using two greywater reuse scenarios, toilet flushing, and food-crop irrigation. They found that treated greywater from the bathroom, laundry, and kitchen could be safely used for toilet flushing. The median range of annual infection risk when using treated greywater was estimated at about $8.8 \times 10^{-15}-8.3 \times 10^{-11}$ per-person-per-year (pppy), which were within the acceptable levels of US Environmental Protection Agency (US EPA) annual infection risk ( $\leq 10^{-4}$ pppy). For food-crop uses, the estimated annual infection risk greywater (bathroom and laundry) reuse was below the thresholds set by US EPA (bathroom $2.8 \times 10^{-8}$ pppy, laundry $4.9 \times 10^{-8}$ pppy). However, kitchen greywater source was not suitable for food-crop irrigation $\left(4.9 \times 10^{-6}\right.$ pppy) [35].

The soil-plant-animal relationships need to be taken into account for a better understanding of metals' impact on grazing animals (e.g., cows). The bioavailability and accumulation of metals (especially, heavy metals) in vegetation are essential parameters to assess the soil-plant relationship and metal translocation to vegetation. Those parameters are governed by the adsorption capacity of the soil, which highly depends on soil $\mathrm{pH}$ organic matter content $[36,37]$. When plant roots uptake those metals and accumulate them in the vegetative parts, they become readily available for grazers. Heavy metals $(\mathrm{Cr}, \mathrm{Cd}$, $\mathrm{Hg}, \mathrm{Pb}$, and $\mathrm{Ni}$ ) are metallic elements, have relatively higher density (heavier) than water, and are highly soluble in the aquatic environments, and therefore, they can be absorbed by living organisms easily [38]. Those metals are readily transferred through food chains and cause potential toxic effects to animal and human health [39]. In fact, heavy metals are critical bio-accumulative toxins in the dairy production system [40]. The uptake of forage containing heavy metals (e.g., $\mathrm{Cd}, \mathrm{Pb}$, and $\mathrm{Hg}$ ) accumulates in animal organs, including liver and kidney, and exerts adverse effects on those domestic animals [41]. When animals (e.g., dairy cows) consume heavy metal-containing feed, those toxic contaminants may transfer to the food products of animal origin, such as liver, meat, and milk, and cause human health problems [42]. Although the concentrations of heavy metals found in the greywater were within the acceptable range suggested by WHO (Table 1), long-term reuse could accumulate those toxic metals in soil and plant. For example, when barely (animal feed) seedling grown in a hydroponic system containing $1.0 \mu \mathrm{g} \mathrm{l^{-1 }} \mathrm{Cd}, 5.0 \mu \mathrm{g} \mathrm{L}^{-1} \mathrm{~Pb}$ and $1 \mu \mathrm{g} \mathrm{l^{-1 }}$ Ni for 9 days, the concentration of $\mathrm{Cd}$ in the shoots was $54 \mu \mathrm{g} \mathrm{kg}{ }^{-1}, \mathrm{~Pb}$, $33 \mu \mathrm{g} \mathrm{kg}-1$ and $\mathrm{Ni} 675 \mu \mathrm{g} \mathrm{kg}^{-1}$ [43]. Given these limitations, the reuse of greywater needs to be considered with caution.

\subsubsection{Ornamentals, Fuel, and Wood Production}

Prosopis and Albizia have been used in landscaping in the Mediterranean region, including Jordan. However, frequent irrigation is required to sustain the aesthetic appearance of those species in the landscape. Greywater has been used for irrigation landscape plants worldwide. Recently, novel ornamental green wall systems for greywater treatment have been developed to cover the aesthetic, environmental, and economic demands for urban areas $[44,45]$. Ornamental plant species such as Carex appressa L., Nephrolepis obliterata L., Myoporum parvifolium L., and Liriope muscari L. were adapted to greywater quality and could be used as aesthetically attractive, on-site greywater treatment system [45]. How- 
ever, the reuse of greywater can lead to environmental problems such as groundwater contamination (e.g., heavy metals and Escherichia coli).

The characteristics and chemical composition of greywater are critical for health and environmental aspects [5]. Greywater reuse for landscaping and wood production is likely to have environmental effects, which may be positive or negative. While greywater can contain plant nutrients that may enhance plant growth, high levels of surfactants, $\mathrm{Na}+$, and pathogenic microorganisms may negatively affect environmental and human health [24]. Generally, greywater is evaluated according to specific quality characteristics and standards to avoid that it poses a risk to the environment or humans $[9,11]$. These standards and quality criteria generally consist of chemical (heavy metals and nutrients) and microbiological parameters (pathogens). However, only specific compounds are measured and the chance of having non-measured possible toxic substances is possible $[9,46]$. The composition of greywater depends on sources (kitchen, bathroom, or laundry) and normally contains lower levels of organic matter and nutrients compared to ordinary wastewater [5]. In fact, greywater is highly variable in quality and may contain some pathogens such as Aeromonas, Salmonella, Pseudomonas, and Staphylococcus; consequently, it should not be reused without treatment [47]. Antibiotic and herbicide analysis in household greywater reuse systems in Palestine revealed that antibiotics and herbicides were widely found in greywater influent [46]. Off-grid greywater reuse systems did not consistently remove atrazine, ciprofloxacin, erythromycin, oxolinic acid, tetracycline, and trifluralin. Antibiotics concentration in greywater influent samples ranging from $1.3 \mathrm{ng} \mathrm{L}^{-1}$ to $1592.9 \mathrm{ng} \mathrm{L}^{-1}$ and herbicides were detected at a range of 3.1-22.4 $\mathrm{ng} \mathrm{L}^{-1}$ [46]. In Australia, a total of 22 organic micro-pollutants, including acesulfame, caffeine, paracetamol, salicylic acid, and triclosan were detected in greywater, and consequently, the reuse of greywater in irrigation of ornamental trees can act as a source of organic micro-pollutants to shallow groundwater and nearby surface water [48]. Therefore, micro-organisms and heavy metals accumulations in soil and groundwater have to be taken into account when greywater is reused [5].

Onsite greywater treatment potentially reduces heavy metals levels, and therefore, those metals should not pose a problem for reuse in toilet flushing or irrigation [49]. However, the essential environmental problems associated with the existence of those toxic metals in greywater are linked to the issue of sludge disposal [49]. Turner et al. [50] compared the accumulation levels of metals in soil, groundwater, and surface water, as a result of greywater reuse in irrigation to national and international guidelines. They found greywater reuse gradually increased soil As, B, Cr, and $\mathrm{Cu}$ and exceeding guidelines after only four years of irrigation. In addition, leaching of metals from the grey-irrigation soil resulted in metal concentrations ( $\mathrm{Al}, \mathrm{As}, \mathrm{Cr}, \mathrm{Cu}, \mathrm{Fe}, \mathrm{Mn}, \mathrm{Ni}$, and $\mathrm{Zn}$ ) in groundwater exceeding environmental quality guidelines after four years. Although the results of Turner et al. [50] are unlikely to be applicable worldwide, the results indicate the necessity to consider metals in greywater in order to reduce the adverse environmental impact from greywater irrigation.

\subsection{Ways for Improvement}

A reduction in residential water demand can be achieved by improving water supply systems, raising public awareness about water-saving, and reusing, specifically, greywater [6]. In fact, the adoption of greywater for the sustainable conservation of water is inevitable, especially in drylands. Some communities are cautious about greywater reuse for irrigation due to the limited information or awareness programs on the potential of greywater reuse as a clean supplement for fresh water [8]. A recent socio-economic study on greywater reuse shows that there is an overall acceptance for using high-quality treated greywater for toilet flushing, laundry, garden irrigation, but not for drinking [51]. In addition, the previous knowledge about greywater reuse, educational level, gender, and age are critical determinants of acceptability [51]. 
This study highlighted the potential reuse of greywater in shrubs/trees that are recognized as forestry trees, which would provide substantial services for the families as cultural services (recreation, landscape, etc.), provisioning services (fuelwood, fodders, etc), especially in drylands [52]. The forestry plantations grown with the greywater would work as a perfect substitute for the industrial forest plantation for fuel production to the local community, besides investing in the fuelwood trading [53]. This would support the national efforts in forestry protection and afforestation projects. The irrigation of forestry plantations with treated greywater is a realistic option for regions with shortages of adequate water resources. Adoption of this approach is clearly profitable due to the fact that the composition of greywater support biomass growth and further tree products. However, uncontrolled planting of Prosopis can lead to serious impacts on water availability and compete with other species for water. The daily average evapotranspiration of a Prosopis tree ranges from $3 \mathrm{~mm}$ to $4 \mathrm{~mm}$, depending on canopy density. In Afar region, the estimated water use of 1.18 million ha of $P$. julifora $\mathrm{L}$. was about 3.1-3.3 billion $\mathrm{m}^{3}$ year $^{-1}$. This volume of water would be sufficient to irrigate about $330,000-460,000$ ha of field crops [54]. Additionally, inefficient utilization and combustion of Prosopis and Albizia solid fuels generates a range of harmful emissions to the environment and could result in global heating. Therefore, the use of greywater for Prosopis and Albizia should be carried out with caution. Overall, legislation should be carried out to encourage farmers to adopt greywater reuse for irrigation crop species that accumulate low concentration of metals in their edible parts (e.g., safflower, sorghum, millet, carrots, radish, cucumber, tomatoes, eggplant, lettuce) and the reuse of greywater should be encouraged as an integral component in each country's national development strategic plan [55]. In addition, regular analysis of greywater, the use of advanced technologies to improve the filtration process, and the dilution of greywater with fresh water to lower the salt and metal toxicity and improve the irrigation water quality.

Author Contributions: Conceptualization, N.K.A.-M., Y.A.O. and M.J.T.; methodology, N.K.A.M., S.T. and A.A.-A.; formal analysis, N.K.A.-M. and Y.A.O.; data curation, Y.A.O. and A.A.-A.; writing—original draft preparation, N.K.A.-M. and M.J.T.; writing—review and editing, Y.A.O.; project administration, M.J.T. and N.K.A.-M. All authors have read and agreed to the published version of the manuscript.

Funding: This research received no external funding.

Institutional Review Board Statement: Not applicable.

Informed Consent Statement: Not applicable.

Data Availability Statement: Not applicable.

Acknowledgments: The authors would like to thank the Deanship of Scientific Research at Jordan University of Science and Technology for supporting this research.

Conflicts of Interest: The authors declare no conflict of interest.

\section{References}

1. Tadros, M.; Al-Mefleh, N.; Othman, Y.; Al-Assaf, A. Water harvesting techniques for improving soil water content, and morphophysiology of pistachio trees under rainfed conditions. Agric. Water Manag. 2021, 243, 106464. [CrossRef]

2. WHO. Guidelines for the Safe Use of Wastewater, Excreta and Greywater; World Health Organization: Geneva, Switzerland, 2006; Volume 2.

3. Khalid, S.; Shahid, M.; Natasha, I.; Sarwar, T.; Shah, A.; Niazi, N. A Review of Environmental Contamination and Health Risk Assessment of Wastewater Use for Crop Irrigation with a Focus on Low and High-Income Countries. Int. J. Environ. Res. Public Health 2018, 15, 895. [CrossRef]

4. Leong, J.; Balan, P.; Chong, M.; Poh, P. Life-cycle assessment and life-cycle cost analysis of decentralized rainwater harvesting, greywater recycling and hybrid rainwater-greywater systems. J. Clean. Prod. 2019, 229, 1211-1224. [CrossRef]

5. Eriksson, E.; Auffarth, K.; Henze, M.; Ledin, A. Characteristics of grey wastewater. Urban Water 2002, 4, 85-104. [CrossRef]

6. Friedler, E.; Hadari, M. Economic feasibility of on-site greywater reuse in multi-storey buildings. Desalination 2006, 190, 221-234. [CrossRef] 
7. Boano, F.; Caruso, A.; Costamagna, E.; Ridolfi, L.; Fiore, S.; Demichelis, F.; Gavão, A.; Pisoeiro, J.; Rizzo, A.; Masi, F. A review of nature-based solutions for greywater treatment: Applications, hydraulic design, and environmental benefits. Sci. Total Environ . 2020, 711, 134731. [CrossRef] [PubMed]

8. Radingoana, M.; Dube, T.; Mazvimavi, D. Progress in greywater reuse for home gardening: Opportunities, perceptions and challenges. Phys. Chem. Earth 2020, 116, 102853. [CrossRef]

9. Leal, L.; Soeter, A.; Kools, S.; Kraak, M.; Parsons, J.; Temmink, H.; Zeeman, G.; Buisman, C. Ecotoxicological assessment of greywater treatment systems with Daphnia magna and Chironomus riparius. Water Res. 2012, 46, 1038-1044. [CrossRef]

10. Al-Hamaiedeh, H.; Bino, M. Effect of treated grey water reuse in irrigation on soil and plants. Desalination 2010, 256, 115-119. [CrossRef]

11. Mzini, L.; Winter, K. Analysis of grey-water used for irrigating vegetables and possible effects on soils in the vicinity of Umtata Dam, Eastern Cape. Water SA 2015, 41, 115-120. [CrossRef]

12. Al-Assaf, A.; Tadros, M.J.; Al-Shishany, S.; Stewart, S.; Majdalawi, M.; Tabieh, M.; Othman, Y.A. Economic Assessment and Community Management of Prosopis juliflora Invasion in Sweimeh Village, Jordan. Sustainability 2020, 12, 8327. [CrossRef]

13. Fagg, C.W.; Stewart, J.L. The value of Acacia and Prosopis in arid and semi-arid environments. J. Arid Environ. 1994, 27, 3-25. [CrossRef]

14. Kumar, S.P.; Prince, W.; Sivakumar, S.; Subbhurram, C. Prosopis juliflora-A green solution to decontaminate heavy metal (Cu and Cd) contaminated soils. Chemosphere 2005, 60, 1493-1496. [CrossRef]

15. Wakie, T.; Laituri, M.; Evangelista, P. Assessing the distribution and impacts of Prosopis juliflora through participatory approaches. Appl. Geogr. 2016, 66, 132-143. [CrossRef]

16. Qrunfleh, M.; Othman, Y. Ornamental Landscape Plants Grown in Jordan and Neighbouring Countries: Woody Ornamental Trees, 1st ed.; Dar Wael for Publishing: Amman, Jordan, 2020; Volume 3, pp. 115-130.

17. Tadros, M.; Al-Assaf, A.; Othman, Y.; Makhamreh, Z.; Taifour, H. Evaluating the effect of Prosopis juliflora, an alien invasive species, on land cover change using remote sensing approach. Sustainability 2020, 12, 5887. [CrossRef]

18. Shankhwar, A.; Srivastava, R. Biomass production through grey water fertigation in Eucalyptus hybrid and its economic significance. Environ. Prog. Sustain. Energy 2015, 34, 222-226. [CrossRef]

19. Zalesny, R.; Stanturf, J.; Evett, S.; Kandil, N.; Sorianos, C. Opportunities for woody crop production using treated wastewater in Egypt. I. Afforestation strategies. Int. J. Phytoremediat. 2011, 13, 102-121. [CrossRef]

20. Al-Hamamre, Z.; Saidan, M.; Hararah, M.; Rawajfeh, K.; Alkhasawneh, H.; Al-Shannag, M. Wastes and biomass materials as sustainable-renewable energy resources for Jordan. Renew. Sust. Energy Rev. 2017, 67, 295-314. [CrossRef]

21. USAID. Water Resources and Environment: Investing in a Water-Secure Future in Jordan. 2020. Available online: https: / / www.usaid.gov /jordan/water-and-wastewater-infrastructure\#: \{\}:text=Jordan $\% 20$ is $\% 20$ one $\% 20$ of $\% 20$ the, as $\% 20$ it $\%$ 20can\%20be\%20recharged (accessed on 24 February 2021).

22. JISM. Water - Reclaimed Grey Water (JS 1776:2013); Jordan Institution for Standards and Meteorology: Amman, Jordan, 2013; pp. 1-12.

23. Radingoana, M.; Dube, T.; Mazvimavi, D. An assessment of irrigation water quality and potential of reusing greywater in home gardens in water-limited environments. Phys. Chem. Earth 2020, 116, 102857. [CrossRef]

24. Siggins, A.; Burton, V.; Ross, C.; Lowe, H.; Horswell, J. Effects of long-term greywater disposal on soil: A case study. Sci. Total Environ. 2016, 557, 627-635. [CrossRef]

25. Disha, A.; Al Harun, M.; Akter, S.; Billah, S.; Abdullah-Al-Noman, M. Reusing greywater for cultivation of Capsicum frutescens and Calendula officinalis. J. Environ. Manag. 2020, 272, 111088. [CrossRef] [PubMed]

26. Mzini, L.; Winter, K. Effects of irrigation water quality on vegetables Part 1: Yield and aesthetical appeal. S. Afr. J. Plant Soil 2015, 32, 27-31. [CrossRef]

27. Al-Ajlouni, M.; Ayad, J.; Othman, Y. Increasing nutrient levels promote growth and flower quality in lilies grown under soilless culture. Hort. Sci. 2017, 44, 171-177. [CrossRef]

28. Leskovar, D.; Othman, Y.; Dong, X. Strip tillage improves soil biological activity, fruit yield and sugar content of triploid watermelon. Soil Tillage Res. 2016, 163, 266-273. [CrossRef]

29. Leskovar, D.; Othman, Y. Nitrogen management for improving root and shoot components of young 'Arbequina' olives. HortScience 2019, 54, 175-180. [CrossRef]

30. Othman, Y.; Leskovar, D. Nitrogen management influenced root length intensity of young olive trees. Sci. Hort. 2019, 246, 726-733. [CrossRef]

31. Tahat, M.; Alananbeh, K.; Othman, Y.; Leskovar, D. Soil health and sustainable agriculture. Sustainability 2020, 12, 4859. [CrossRef]

32. Jarrell, W.; Beverly, R. The dilution effect in plant nutrition studies. Adv. Agron. 1981, 34, 197-224. [CrossRef]

33. Shaikh, I.; Ahammed, M. Quantity and quality characteristics of greywater: A review. J. Environ. Manag. 2020, $261,110266$. [CrossRef] [PubMed]

34. Finley, S.; Barrington, S.; Lyew, D. Reuse of domestic greywater for the irrigation of food crops. Water Air Soil Pollut. 2009, 199, 235-245. [CrossRef]

35. Shi, K.; Wang, C.; Jiang, S. Quantitative microbial risk assessment of Greywater on-site reuse. Sci. Total Environ. 2018, 635, 1507-1519. [CrossRef] [PubMed] 
36. Roggeman, S.; van den Brink, N.; Van Praet, N.; Blust, R.; Bervoets, L. Metal exposure and accumulation patterns in freerange cows (Bos taurus) in a contaminated natural area: Influence of spatial and social behavior. Environ. Pollut. 2013, 172, 186-199. [CrossRef]

37. Tudoreanu, L.; Phillips, C. Modeling cadmium uptake and accumulation in plants. Adv. Agron. 2004, 84, 121-157. [CrossRef]

38. Kinuthia, G.; Ngure, V.; Beti, D.; Lugalia, R.; Wangila, A.; Kamau, L. Levels of heavy metals in wastewater and soil samples from open drainage channels in Nairobi, Kenya: Community health implication. Sci. Rep. 2020, 10, 8434. [CrossRef]

39. López-Alonso, M. Animal feed contamination by toxic metals. In Animal Feed Contamination, Effects on Livestock and Food Safety; Fink-Gremmels, J., Ed.; Woodhead Publishing Limited: Cambridge, UK, 2012; pp. 183-204.

40. Li, Y.; McCrory, D.; Powell, J.; Saam, H.; Jackson-Smith, D. A survey of selected heavy metal concentrations in Wisconsin dairy feeds. J. Dairy Sci. 2005, 88, 2911-2922. [CrossRef]

41. Rajaganapathy, V.; Xavier, F.; Sreekumar, D.; Mandal, P. Heavy metal contamination in soil, water and fodder and their presence in livestock and products: A review. J. Environ. Sci. Technol. 2011, 4, 234-249. [CrossRef]

42. Adamse, A.; Van der Fels-Klerx, H.; de Jong, J. Cadmium, lead, mercury and arsenic in animal feed and feed materials-trend analysis of monitoring results. Food Addit. Contam. Part A 2017, 34, 1298-1311. [CrossRef]

43. Al-Ajmi, A.; Salih, A.; Kadim, I.; Othman, Y. Chemical constituents and heavy metals contents of barley fodder produced under hydroponic system in GCC countries using tertiary treated sewage effluents. J. Phytol. 2009, 1, 374-380.

44. Prodanovic, V.; Hatt, B.; McCarthy, D.; Zhang, K.; Deletic, A. Green walls for greywater reuse: Understanding the role of media on pollutant removal. Ecol. Eng. 2017, 102, 625-635. [CrossRef]

45. Prodanovic, V.; McCarthy, D.; Hatt, B.; Deletic, A. Designing green walls for greywater treatment: The role of plants and operational factors on nutrient removal. Ecol. Eng. 2019, 130, 184-195. [CrossRef]

46. Craddock, H.; Panthi, S.; Rjoub, Y.; Lipchin, C.; Sapkota, A.; Sapkota, A. Antibiotic and herbicide concentrations in household greywater reuse systems and pond water used for food crop irrigation: West Bank, Palestinian Territories. Sci. Total Environ. 2020, 699, 134205. [CrossRef]

47. Leong, J.; Oh, K.; Poh, P.; Chong, M. Prospects of hybrid rainwater-greywater decentralised system for water recycling and reuse: A review. J. Clean. Prod. 2017, 142, 3014-3027. [CrossRef]

48. Turner, R.; Warne, M.; Dawes, L.; Thompson, K.; Will, G. Greywater irrigation as a source of organic micro-pollutants to shallow groundwater and nearby surface water. Sci. Total Environ. 2019, 669, 570-578. [CrossRef] [PubMed]

49. Eriksson, E.; Donner, E. Metals in greywater: Sources, presence and removal efficiencies. Desalination 2009, 248, 271-278. [CrossRef]

50. Turner, R.; Warne, M.; Dawes, L.; Vardy, S.; Will, G. Irrigated greywater in an urban sub-division as a potential source of metals to soil, groundwater and surface water. J. Environ. Manag. 2016, 183, 806-817. [CrossRef] [PubMed]

51. Amaris, G.; Dawson, R.; Gironás, J.; Hess, S.; Ortúzar, J. Understanding the preferences for different types of urban greywater uses and the impact of qualitative attributes. Water Res. 2020, 184, 116007. [CrossRef]

52. Al-Assaf, A.; Nawash, O.; Mmari, M. Identifying forest ecosystem services through socio-ecological bundles a case study from northern Jordan. Int. J. Sustain. Dev. World Ecol. 2014, 21, 314-321. [CrossRef]

53. Midgley, S.; Stevens, P.; Arnold, R. Hidden assets: Asia's smallholder wood resources, and their contribution to supply chains of commercial wood. Aust. For. 2017, 80, 10-25. [CrossRef]

54. Shiferaw, H.; Alamirew, T.; Dzikiti, S.; Bewket, W.; Zeleke, G.; Schaffner, U. Water use of Prosopis juliflora and its impacts on catchment water budget and rural livelihoods in Afar Region, Ethiopia. Sci. Rep. 2021, 11, 2688. [CrossRef]

55. Hussain, M.; Muscolo, A.; Farooq, M.; Ahmad, W. Sustainable use and management of non-conventional water resources for rehabilitation of marginal lands in arid and semiarid environments. Agric. Water Manag. 2019, 221, 462-476. [CrossRef] 